\title{
Vegetation analysis and estimation of forest reconstitution time in protected areas of Val Camonica (Southern Alps) where a commercial mixture of seeds was sown
}

\author{
Luca Giupponi, Gian Battista Bischetti \& Annamaria Giorgi
}

Keywords: chronosequence, floristic-vegetational indices, maturity, restoration, seed mixture

\section{Abstract}

Profile

This study examined the vegetation composition of five sites of the Southern Alps (Val Camonica, Italy) where a commercial seed mixture had been used to restore vegetation at the end of soil stabilization works. The five sites are located in two protected areas of the Alps (the Parco dell'Adamello and the Riserva Naturale delle Valli di Sant'Antonio), and represent a chronosequence of year of sowing. We used a set of floristic-vegetational indices (index of maturity, indices of the life forms, and Landolt ecological indices) to analyse the characteristics of the vegetation of the five sites and to find a model that would allow an estimation of forest reconstitution time. From data analysis we found that, in areas which have had more recovery time, the sown heliophilous species and the ruderal herbaceous species decrease, while shrubs, trees and typical species of mature forests increase. The values of the index of maturity also increase according to time elapsed after sowing; the relationship that, in the present case, links the index of maturity to time was expressed formulaically. This model provided an estimation of the time required for the reconstitution of the forest community which, in this case, was about twenty years. This research, prompted by a request from the managing institutions of the two protected areas for a botanical investigation into the outcome of using the seed mixture, provided information that will enable them to assess whether to use the mixture in future environmental restoration work in the same areas.
Protected area

Parco dell'Adamello

and the Riserva Na-

turale delle Valli di

\section{Sant'Antonio}

Mountain range

Alps

Country

Italy

\section{Introduction}

The environmental restoration of areas affected by destructive phenomena (anthropogenic and/or natural) is currently a priority issue for those involved in land management (Aronson \& Alexander 2013), in particular in protected mountain areas. Many mountain ecosystems with high biodiversity are vulnerable to soil erosion which, in some cases, may evolve to endanger human activity and the environment. Different methods are, therefore, used to protect the land from soil erosion and mitigate damage, including hydraulicforestry intervention. In the past such projects were carried out without considering their impact on the ecosystem, but techniques and materials with a low environmental impact typical of soil bioengineering have been used since the middle of the $20^{\text {th }}$ century (Bischetti et al. 2012). The choice of plant species and procedures is of great importance in the restoration of the vegetation. In recent years, studies have been carried out on various techniques for creating seminatural grassland in restoration projects (ÖAG 2000; Kiehl et al. 2010; Hagen et al. 2014), and seed mixtures suitable for varied environments have been marketed. Although these mixtures allow the creation of turf with a satisfactory aesthetic appearance in the first years after sowing, there are no in-depth studies regarding the vegetation dynamics of the areas in which they have been used. Data to aid understanding as to whether these seed mixtures are effective for the reconstitution of structurally more complex and more advanced plant communities (such as forest), present before the disturbance, are therefore lacking. Knowledge of what may happen in a vegetation system after sowing a seed mixture is of great importance to those involved in land management and, even more so, for those involved in the environmental restoration of natural landscapes in protected areas. In the present case, the managers of two protected areas (the Parco dell'Adamello and the Riserva Naturale delle Valli di Sant'Antonio) of the Val Camonica (northern Italy) requested a study of the floristic, ecological and dynamic character of the vegetation which developed following the sowing of a mixture of commercial seeds, in various sites within the two areas, so as to understand the effects of sowing the mixture and to evaluate its potential for use in future environmental restoration work in the same areas.

In order to meet the needs of the managing institutions, the study examined the vegetation composition of five mountain sites where the commercial seed mixture had been sown (in different years) to restore vegetation. In addition to the floristic and ecological analysis of the vegetation, this study also aimed to devise a model to estimate the time required for forest community reconstitution after sowing, hence testing the index of maturity developed by Taffetani and Rismondo (2009). 


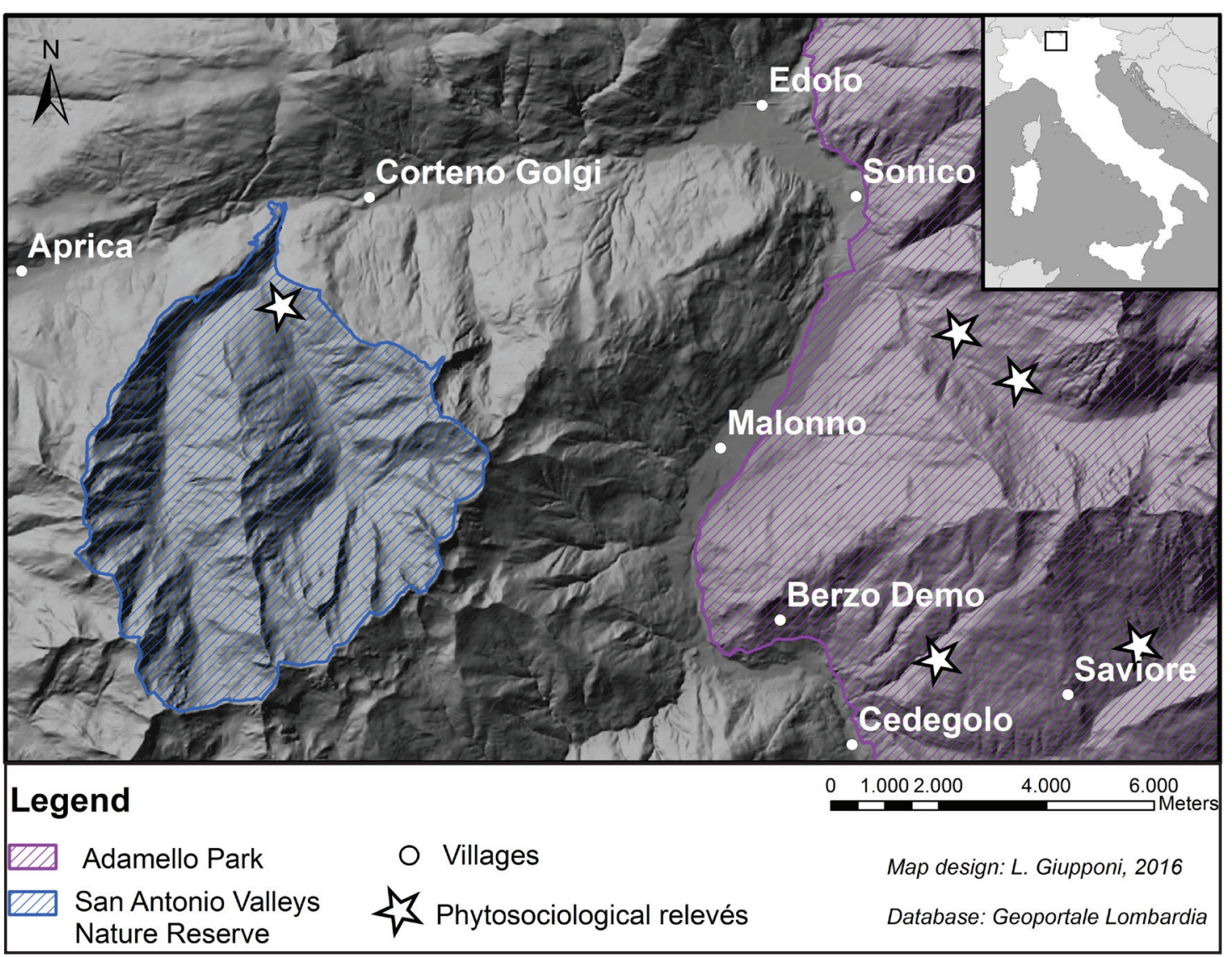

Figure 1 - Study area (latitude: $46^{\circ} 07^{\prime} 48,87^{\prime \prime} N$, longitude: $10^{\circ} 18^{\prime} 38,59^{\prime \prime} \mathrm{E}$ ). The stars indicate the five sites where the phytosociological relevés were carried out.

\section{Materials and methods}

\section{Study areas}

The study analysed the vegetation of five sites situated in the upper Val Camonica (Lombardy, Northern Italy) in the municipalities of Saviore dell'Adamello, Corteno Golgi, Sonico and Cevo, four of which are situated within the the Parco dell'Adamello and one in the Riserva Naturale delle Valli di Sant'Antonio (SIC IT2070017) (Figure 1). These sites belong to the same land unit have similar environmental characteristics, and were subject to land stabilization work using traditional and soil bioengineering techniques. In particular, crib-walls to protect roads, and weirs and channels to control the waters of streams and stabilize banks, were constructed in the five areas. Work was carried out in different periods (from 2000 to 2012) by the Consorzio Forestale Alta Val Camonica, which used the same mixture of seeds. The five sites represented a chronosequence for the year of sowing (2012, $2011,2009,2005,2000)$. Although they are small (50$150 \mathrm{~m}^{2}$ ), they were selected because of their similar altitude, exposure, slope and substratum.

The area studied has a rainfall of over $1000 \mathrm{~mm}$ per year, concentrated mainly in the spring and the autumn; the annual average temperature is about $8,5^{\circ} \mathrm{C}$; minimum temperatures and precipitation are during the winter months. According to the recent classifi-
Table 1 - Physical-chemical properties of a typical Cambic Podzol soil of the upper Val Camonica. Data source: Previtali et al. (1992)

\begin{tabular}{|l|r|r|r|r|r|r|}
\hline $\begin{array}{l}\text { Soil hori- } \\
\text { zon }\end{array}$ & $\begin{array}{l}\text { Depth } \\
\text { (cm) }\end{array}$ & $\begin{array}{l}\text { Sand } \\
\text { (\%) }\end{array}$ & $\begin{array}{l}\text { Silt } \\
\text { (\%) }\end{array}$ & $\begin{array}{l}\text { Clay } \\
\text { (\%) }\end{array}$ & pH & $\begin{array}{l}\text { Organic } \\
\text { matter (\%) }\end{array}$ \\
\hline Ah & $0-7,5$ & 77.8 & 14.8 & 7.4 & 4.0 & 32.35 \\
\hline E & $7,5-10$ & 51.8 & 37.3 & 10.9 & 3.7 & 7.40 \\
\hline Bs1 & $10-20$ & 77.4 & 17.4 & 5.2 & 4.0 & 8.75 \\
\hline Bs2 & $20-40$ & 83.1 & 12.9 & 4.0 & 3.9 & 8.26 \\
\hline CB & $40-45$ & 66.5 & 23.3 & 10.2 & 4.2 & 3.81 \\
\hline
\end{tabular}

cation of the ecoregions of Italy (Blasi et al. 2014), the area is within the Central and Eastern Alps section (Alpine Province, Temperate Division). The vegetation sampling sites are situated in the montane belt (1190 m-1310 m) where potential vegetation consists of dense spruce forests belonging to the Piceion excelsae alliance (Verde et al. 2010) on soils with an acid to very acid reaction (Cambic Podzols) due to the crystalline geological substratum (Previtali et al. 1992). Table 1 shows the chemo-physical characteristics of a Cambic Podzol typical of the upper Val Camonica. In the five sites where the relevés were performed, the soil was highly disturbed and altered due to the soil stabilization work done which, in some cases, had exposed the bedrock. Nevertheless, no allochthonous soil was added; the soil that had been removed during excavation 
Table 2 - Phytosociological table of relevés according to the sequence given by cluster analysis. Percentages of seeds are listed for the mixture (code $\left.=1^{*}\right)$. Syntaxonomical classes are listed according to the coefficient of maturity $(\mathrm{m})$. The groups of species that characterize the three clusters are bighlighted by boxes. The symbols related to life forms are those proposed by Raunkiaer (1934): H, hemicryptophytes; T, therophytes; G, geophytes; NP, nano-phanerophytes; P, phanerophytes; Ch, chamaephytes.

\begin{tabular}{|c|c|c|c|c|c|c|c|c|c|c|c|c|}
\hline & & & & Relevé code & $1^{*}$ & 2 & 3 & 4 & 5 & 6 & & \\
\hline & & & & Cluster & $\mathrm{A}$ & $\mathrm{A}$ & $\mathrm{A}$ & $B$ & $\mathrm{C}$ & $C$ & & \\
\hline & & & & Year of sowing & - & 2012 & 2011 & 2009 & 2005 & 2000 & & \\
\hline & & & & Protected Area & - & $\begin{array}{c}\text { Adamello } \\
\text { Park }\end{array}$ & $\begin{array}{l}\begin{array}{c}\text { S. Antonio } \\
\text { Valleys }\end{array} \\
\end{array}$ & $\begin{array}{c}\text { Adamello } \\
\text { Park }\end{array}$ & $\begin{array}{c}\text { Adamello } \\
\text { Park }\end{array}$ & $\begin{array}{c}\text { Adamello } \\
\text { Park }\end{array}$ & & \\
\hline & & & & Latitude N & - & $46^{\circ} 05^{\prime} 18.6^{\prime \prime}$ & $46^{\circ} 08^{\prime} 51.5^{\prime \prime}$ & $46^{\circ} 08^{\prime} 28.8^{\prime \prime}$ & $46^{\circ} 07^{\prime} 59.5^{\prime \prime}$ & $46^{\circ} 05^{\prime} 11.8^{\prime \prime}$ & & \\
\hline & & & & Longitude E & - & $10^{\circ} 25^{\prime} 07.1^{\prime \prime}$ & $10^{\circ} 12^{\prime} 50.2^{\prime \prime}$ & $10^{\circ} 22^{\prime} 35.4^{\prime \prime}$ & $10^{\circ} 23^{\prime} 27.2^{\prime \prime}$ & $10^{\circ} 22^{\prime} 12.8^{\prime \prime}$ & & \\
\hline & & & & Altitude $(\mathrm{m})$ & - & 1310 & 1240 & 1190 & 1290 & 1220 & & \\
\hline & & & & Investigated area $\left(\mathrm{m}^{2}\right)$ & - & 25 & 25 & 25 & 25 & 25 & & \\
\hline & & & & Slope $\left({ }^{\circ}\right)$ & - & 36 & 26 & 45 & 45 & 6 & & \\
\hline & & & & Exposure $\left({ }^{\circ}\right)$ & - & 100 & 90 & 200 & 180 & 210 & & \\
\hline & & & & Trees cover (\%) & - & 0 & 0 & 0 & 0 & 35 & & \\
\hline & & & & Shrubs cover (\%) & - & 0 & 0 & 5 & 20 & 15 & & \\
\hline & & & & Herbaceous cover (\%) & - & 65 & 85 & 60 & 45 & 30 & & \\
\hline & & & & Max height of trees (m) & - & 0 & 0 & 0 & 0 & 5 & & \\
\hline & & & & Max height of shrubs (m) & - & 0 & 0 & 1 & 1.5 & 1.5 & & \\
\hline & & & & Max height of grass (m) & - & 1.5 & 1.2 & 1 & 1.5 & 0.8 & & \\
\hline & & & & Landolt indices & & & & & & & & \\
\hline & & & & $T$ - temperature & 3.20 & 3.24 & 3.42 & 3.06 & 2.98 & 3.08 & & \\
\hline & & & & $\mathrm{K}$ - continentality & 3.07 & 3.03 & 2.99 & 3.06 & 3.30 & 3.17 & & \\
\hline & & & & L - light intensity & 3.32 & 3.28 & 3.59 & 3.05 & 2.89 & 3.15 & & \\
\hline & & & & F-soil moisture & 2.96 & 3.01 & 2.95 & 2.69 & 2.87 & 2.89 & & \\
\hline & & & & $\mathbf{R}$-substrate reaction & 2.93 & 2.97 & 3.00 & 2.47 & 2.89 & 2.93 & & \\
\hline & & & & $\mathbf{N}$ - nutrients & 3.22 & 3.51 & 3.37 & 2.47 & 2.86 & 2.97 & & \\
\hline & & & & H - humus & 3.16 & 3.08 & 3.05 & 4.09 & 3.50 & 3.25 & & \\
\hline & & & & D - aeration & 1.34 & 1.61 & 2.32 & 1.63 & 2.54 & 1.90 & & \\
\hline & & & & CSR strategy & & & & & & & & \\
\hline & & & & C - competitors (\%) & 36.40 & 37.50 & 35.70 & 38.80 & 45.80 & 67.40 & & \\
\hline & & & & S - stress-tolerators (\%) & 30.70 & 25.70 & 29.40 & 33.30 & 30.70 & 17.90 & & \\
\hline & & & & $\mathbf{R}$ - ruderals (\%) & 32.90 & 36.80 & 34.90 & 27.90 & 23.50 & 14.70 & & \\
\hline Life & Chorotype & Provenance & sown & Name of species & & & Numb & er of species & & & Pres. & Matu- \\
\hline form & & of seeds & species & & 12 & 23 & 21 & 25 & 36 & 29 & $\%$ & rity (m) \\
\hline & & & & STELLARIETEA MEDIAE Tüxen. Lo & r \& Preisi & ing ex Von Roch & ow 1951 & & & & & 1 \\
\hline$T$ & Avv. & - & & Erigeron canadensis $\mathrm{L}$. &. & + & + & . &. & . & 33 & \\
\hline & & & & ARTEMISIETEA VULGARIS Lohme & eising \& 7 & Tüxen ex Von Ro & chow 1951 & & & & & 3 \\
\hline$T$ & Subcosmop. & - & & Geranium robertianum L. &. & + & 1 & . &. & . & 33 & \\
\hline $\mathrm{H}$ & Europ.-Caucas. & - & & Rumex obtusifolius L. &. & + & + & . & . & 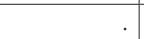 & 33 & \\
\hline $\mathrm{H}$ & Subcosmop. & - & & Urtica dioica $\mathrm{L}$. &. & 1 & + & . &. & . & 33 & \\
\hline $\mathrm{T}$ & Eurasiat. & - & & Galium aparine L. & $\cdot$ & 1 & $\cdot$ & . & . & & 17 & \\
\hline $\mathrm{H}$ & Europ.-Caucas. & - & & Verbascum thapsus $\mathrm{L}$. &. & + &. & . & . & & 17 & \\
\hline & & & & MOLINIO-ARRHENATHERETEA T & 937 & & & & & & & 4 \\
\hline $\mathrm{H}$ & Eurosib. & A & ** & Achillea millefolium L. & 0.2 & + & 1 & + & + & + & 100 & \\
\hline $\mathrm{H}$ & Circumbor. & $\mathrm{NL}$ & ** & Agrostis capillaris L. & 1.0 & + & + & 2 & + & + & 100 & \\
\hline $\mathrm{H}$ & Paleotemp. & DK & ** & Dactylis glomerata L & 5.0 & 1 & 2 & + & + & + & 100 & \\
\hline $\mathrm{H}$ & Paleotemp. & $\mathrm{DE}$ & ** & Trifolium repens $\mathrm{L}$. & 2.0 & + & + & + & + & + & 100 & \\
\hline $\mathrm{H}$ & Circumbor. & DK & ** & Festuca rubra L. & 59.8 & 2 & 2 & 1 & + & . & 83 & \\
\hline $\mathrm{H}$ & Circumbor. & $\mathrm{DE}$ & *** & Phleum pratense L. & 3.0 & + & + & + &. &. & 67 & \\
\hline $\mathrm{H}$ & Subcosmop. & NZ & ** & Trifolium pratense L. & 2.0 & 1 & 2 & . & + & + & 83 & \\
\hline $\mathrm{H}$ & Eurasiat. & DK & ** & Festuca pratensis Huds. & 3.0 & + & + &. &. &. & 50 & \\
\hline $\mathrm{H}$ & Circumbor. & DK & ** & Lolium perenne L. & 10.0 & + & + & . &. &. & 50 & \\
\hline $\mathrm{H}$ & Circumbor. & DK & ** & Poa pratensis L. & 6.0 & + & + & . &. &. & 50 & \\
\hline & Paleotemp. & - & & Lotus corniculatus L. & . & + & . & . & + &. & 33 & \\
\hline & Paleotemp. & - & & Silene dioica (L.) Clairv. &. & + &. & . &. &. & 17 & \\
\hline & Subcosmop. & - & & Silene vulgaris (Moench) Garcke &. & + &. & . &. &. & 17 & \\
\hline & Circumbor. & - & & Taraxacum officinale Weber &. &. &. & . &. & + & 17 & \\
\hline & Eurimedit.-Subatl. & CDN & ** & Trifolium hybridum L. & 1.0 &. &. & . &. &. & 17 & \\
\hline & & & & KOELERIO GLAUCAE-CORYNEP & IEA CAN & ESCENTIS Klika & in Klika \& V. No & vák 1941 & & & & 5 \\
\hline $\mathrm{H}$ & $\begin{array}{l}\text { Centro- Nor- } \\
\text { deurop }\end{array}$ & DK & ** & Festuca ovina agg. & 7.0 & + & + & + & + & + & 100 & \\
\hline $\mathrm{H}$ & Art.Alp. & - & & Silene rupestris $\mathrm{L}$. &. &. &. & + & + & . & 33 & \\
\hline & & & & FESTUCO-SESLERIETEA Barbéro & in 1969 & & & & & & & 5 \\
\hline $\mathrm{H}$ & Orof. S-Europ. & - & & Myosotis alpestris F.W. Schmidt &. &. & + & . & + &. & 33 & \\
\hline & & & & ASPLENIETEA TRICHOMANIS (Br & Meier \& & Br.-BI. 1934) O & berdorfer 1977 & & & & & 5 \\
\hline $\mathrm{H}$ & Endem. Alp. & - & & Phyteuma scheuchzeri All. &. &. &. & . & + & . & 17 & \\
\hline
\end{tabular}




\begin{tabular}{|c|c|c|c|c|c|c|c|c|c|c|}
\hline \multirow[b]{2}{*}{$\mathrm{H}$} & \multirow[b]{2}{*}{ Eurasiat. } & \multirow[b]{2}{*}{-} & \multicolumn{7}{|c|}{ FESTUCO VALESIACAE-BROMETEA ERECTI Br.-BI. \& Tüxen ex Br.-BI. 1949} & \multirow[t]{2}{*}{5} \\
\hline & & & Ranunculus bulbosus L. & & ++ & . & & & 17 & \\
\hline \multirow[t]{2}{*}{$\mathrm{H}$} & Endem. Alp. & - & Avenula praeusta (Rchb.) Holub & & & . & & + & 17 & \\
\hline & & & \multicolumn{7}{|c|}{ TRIFOLIO MEDII-GERANIETEA SANGUINEI Müller 1962} & 7 \\
\hline $\mathrm{H}$ & Europ.-Caucas. & - & Hypericum montanum L. & & & + & + & & 33 & \\
\hline $\mathrm{H}$ & Paleotemp. & - & Hypericum perforatum L. & & & + & & + & 33 & \\
\hline \multirow[t]{2}{*}{$\mathrm{H}$} & S-Europ.-Sudsiber. & - & Veronica chamaedrys L. & & & . & + & & 17 & \\
\hline & & & \multicolumn{7}{|c|}{ MULGEDIO ALPINI-ACONITETEA VARIEGATI Hadač \& Klika in Klika \& Hadač 1944} & 7 \\
\hline \multirow[t]{2}{*}{$\mathrm{H}$} & Orof. S-Europ. & - & Saxifraga rotundifolia L. & & + &. & . & & 17 & \\
\hline & & & \multicolumn{7}{|c|}{ EPILOBIETEA ANGUSTIFOLII Tüxen \& Preising ex Von Rochow 1951} & 7 \\
\hline $\mathrm{H}$ & Circumbor. & - & Epilobium angustifolium L. & + & & & 1 & 1 & 50 & \\
\hline \multirow[t]{2}{*}{$\mathrm{H}$} & Eurosib. & - & Fragaria vesca L. & . & & 1 & 1 & 1 & 50 & \\
\hline & & & \multicolumn{7}{|c|}{ RHAMNO CATHARTICAE-PRUNETEA SPINOSAE Rivas Goday \& Borja ex Tüxen 1962} & 8 \\
\hline $\mathrm{P}$ & Europ.-Caucas. & - & Corylus avellana L. & $\dot{\theta}$ & & + & + & 1 & 50 & \\
\hline $\mathrm{P}$ & Eurasiat. & - & Salix caprea L. & . & & + & + & 2 & 50 & \\
\hline $\mathrm{P}$ & Eurosib. & - & Populus tremula L. & & 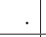 & . & + & 1 & 33 & \\
\hline NP & Circumbor. & - & Rubus idaeus L. & . & r. &. & 1 & 1 & 33 & \\
\hline NP & Eurimedit. & - & Rubus ulmifolius Schott & & . & . & . & + & 17 & \\
\hline \multirow[t]{2}{*}{$\mathrm{P}$} & Europ. & - & Sorbus aucuparia L. & . & & + & . &. & 17 & \\
\hline & & & \multicolumn{7}{|c|}{ QUERCO ROBORIS-FAGETEA SYLVATICAE Br.-BI. \& Vlieger in Vlieger 1937} & 9 \\
\hline G & Circumbor. & - & Oxalis acetosella $\mathrm{L}$. & + & + & + & + & + & 83 & \\
\hline G & $\begin{array}{l}\text { Orof. Centro- } \\
\text { Europ. }\end{array}$ & - & Petasites albus (L.) Gaertn. & + & + & & + & + & 67 & \\
\hline H & Europ.-Caucas. & - & $\begin{array}{l}\text { Chaerophyllum hirsutum subsp. vil- } \\
\text { larsii (W.D.J. Koch) Briq. }\end{array}$ & . & & + & + & + & 50 & \\
\hline $\mathrm{P}$ & Europ.-Caucas. & - & Fraxinus excelsior L. & . & . & + & + & + & 50 & \\
\hline$P$ & Orof. S-Europ. & - & $\begin{array}{l}\text { Laburnum alpinum (Mill.) Bercht. \& } \\
\text { J. Presl }\end{array}$ & $\cdot$ & & + & + & + & 50 & \\
\hline $\mathrm{H}$ & Orof. SW-Europ. & - & Luzula nivea (L.) D.C. & . &. & + & 1 & + & 50 & \\
\hline T & Eurosib. & - & Melampyrum pratense L. & . &. & + & + & 1 & 50 & \\
\hline $\mathrm{H}$ & Eurosib. & - & Hieracium mororum L. & . & . & . & + & + & 33 & \\
\hline $\mathrm{H}$ & SE-Europ. & - & Knautia drymeia Heuff. & . & . & + & + & . & 33 & \\
\hline $\mathrm{H}$ & Endem. Alp. & - & Phyteuma betonicifolium Vill. & . & . & + & + & . & 33 & \\
\hline $\mathrm{H}$ & Europ.-Caucas. & - & Lamium flavidum F. Herm. & . & . & . & + & . & 17 & \\
\hline G & Paleotemp. & - & Platanthera bifolia (L.) Rich. & . & . & & + & . & 17 & \\
\hline $\mathrm{H}$ & S-Europ.-Sudsiber. & - & Ranunculus nemorosus DC. & . & . & . & + & & 17 & \\
\hline G & Subcosmop. & - & Dryopteris filix-mas (L.) Schott & . & & & + & . & 17 & \\
\hline $\mathrm{H}$ & Circumbor. & - & Solidago virgaurea $\mathrm{L}$. & . &. & . & + & . & 17 & \\
\hline $\mathrm{H}$ & Eurasiat. & - & Veronica officinalis L. & & & + & . & . & 17 & \\
\hline $\mathrm{H}$ & Paleotemp. & - & $\begin{array}{l}\text { Brachypodium sylvaticum (Huds.) } \\
\text { Beauv. }\end{array}$ & & & + & . & & 17 & \\
\hline NP & Paleotemp. & - & Solanum dulcamara L. & & & + & . & . & 17 & \\
\hline NP & Centro-Europ. & - & Hippocrepis emerus (L.) Lassen & & & & . & + & 17 & \\
\hline $\mathrm{P}$ & Eurosib. & - & Betula pendula Roth & & & & . & 1 & 17 & \\
\hline \multirow[t]{2}{*}{$\mathrm{H}$} & Europ.-Caucas. & - & Stellaria nemorum subsp. nemorum L. & & + & . & . & & 17 & \\
\hline & & & \multicolumn{7}{|c|}{ VACCINIO MYRTILLI-PICEETEA ABIETIS Br.-Bl. in Br.-Bl., Sissingh \& Vlieger 1939} & 9 \\
\hline G & Paleotemp. & - & Dactylorhiza fuchsii (Druce) Soó & & & & + & + & 33 & \\
\hline $\mathrm{P}$ & Eurosib. & - & Picea abies (L.) H. Karst. & & & & + & + & 33 & \\
\hline$P$ & $\begin{array}{l}\text { Orof. Centro- } \\
\text { Europ. }\end{array}$ & - & Larix decidua Mill. & & & & & + & 17 & \\
\hline
\end{tabular}

activities was used, together with fine soil retrieved locally, in order to reconstitute a layer of fertile soil (about $30 \mathrm{~cm}$ deep) suitable for sowing.

The sites belong to the alpine acidophilus dynamic series of silver fir and spruce (Calamagrostio arundinaceae-Piceo excelsae sigmetum) whose dynamic stages consist of: fringe of Calamagrostion arundinaceae, mantle of Sambuco racemosae-Salicion capreae (Rubetum idaei, PiceoSorbetum aucupariae), and wood of Piceion excelsae (Verde et al. 2010). Each of the five areas borders with mountain forest that is characterized almost exclusively by spruce (Picea abies) in the tree layer, while the shrub and herbaceous layer presents Rubus idaeus, Vaccinium myrtillus, Oxalis acetosella, Hieracium murorum, Luzula nivea, Atbyrium filix-femina, Saxifraga cuneifolia, Maianthemum bifolium and Viola biflora. This forest, present in the five areas before the land stabilization work, represents the current potential vegetation.

\section{Seed mixture}

The mixture of seeds used for grassing is a commercial product; both floristic composition and seed provenance are known (Table 2). The mixture consists solely of perennial herbaceous species typical of mowed meadows (Molinio-Arrhenatheretea), of which graminaceous species are $94.8 \%$ by weight. The seeds come from several states in Northern Europe, though mainly from Denmark. This mixture was designed to be used in mountainous areas of the Alps and Apennines, mostly to grass ski slopes and areas affected by 
human activities, and / or in environmental restoration work. In the areas studied, grassing was performed with hydroseeding (dosage: $30-35 \mathrm{~g} / \mathrm{m}^{2}$ ).

\section{Vegetation sampling and data analysis}

Five phytosociological relevés were performed (one for each site indicated in Figure 1), according to the method of the Zurich-Montpellier Sigmatist School (Braun-Blanquet 1964), and checked periodically from May to September 2014 (the maximal cover of the season was used for each species). The size of sampling plots was $25 \mathrm{~m}^{2}$ ( $\left.5 \mathrm{~m} \times 5 \mathrm{~m}\right)$, and the relevés were carried out in plots that are indicative of the vegetation of the five sites. Species were determined using Pignatti's (1982) dichotomous keys, and cover indices were assigned using the abundance-dominance scale of Pignatti \& Mengarda (1962). Cluster analysis was performed using the Unweighted Pair Group Method with Arithmetic Mean (UPGMA) and chord distance coefficient in order to highlight the floristic-physiognomic similarities of the relevés.

The ecological indices of Landolt et al. (2010) were used to analyse the ecological requirements of the vegetation. The following floristic-vegetation indices proposed by Taffetani \& Rismondo (2009) and updated by Rismondo et al. (2011) were used in order to assess the environmental quality of the sites and the dynamic stage of the vegetation: indices of the life forms (IT = index of therophytic component; $\mathrm{IH}=$ index of hemicryptophytic component; IF = index of perennial non-hemicryptophytic component) and index of maturity (IM). The indices of life forms express the proportion of species cover belonging to one group. IF is useful to determine the evolution of the vegetation towards stable coenoses with low disturbance levels (such as the coenoses of forests), including geophytes, chamaephytes, nano-phanerophytes and phanerophytes. IM measures the stage of maturity of a plant community in relation to the coverage and phytosociological class to which each species belongs; it is the weighted average of the maturity coefficient $(m)$ of each species, weighted by species cover. The coefficient of maturity $(m)$ is the value assigned by Taffetani \& Rismondo (2009) and Rismondo et al. (2011) to the main phytosociological classes of European vegetation according to the physiognomic-structural and synecological characteristics and the syndynamic role of the vegetation in each class. It varies from 0 (cultivated or exotic species that have no evolutionary significance and are therefore not attributable to specific syntaxonomic classes) to 9 (species of the forest vegetation classes). Various sources (manuals, scientific papers and internet sites) were consulted regarding the phytosociological classification. Data regarding the CSR strategy (Grime 2001) of each species were extrapolated from Landolt et al. (2010).

Statistical analyses were performed using the software R 3.2.1 (R Development Core Team 2015). Scientific names of species are according to Martini et

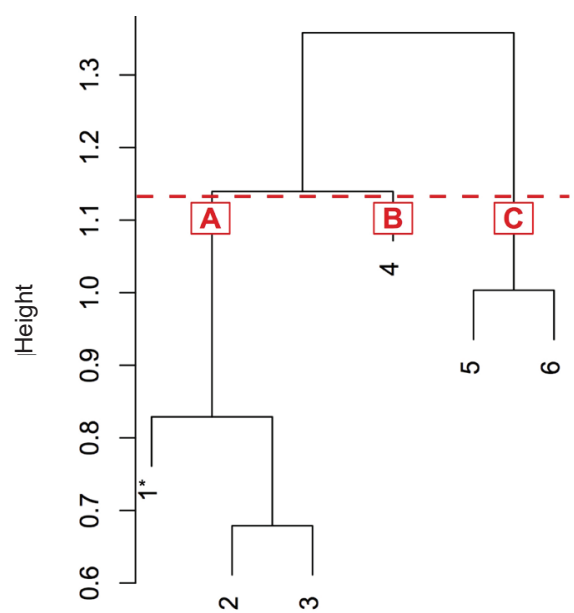

Figure $2-$ Dendrogram of relevés $\left(1^{*}=\right.$ seed mixture $)$ divided into three clusters $(A, B$ and $C)$.

al. (2012); names of phytosociological classes follow Biondi et al. (2014).

\section{Results}

In the five areas sampled, 63 plant species were identified, the majority of which are common or very common in the central and eastern Lombardy area (Martini et al. 2012). Avenula praeusta and Hypericum perforatum are the only two uncommon species identified. Figure 2 presents the dendrogram of the relevés (and the mixture of seeds) separated into three main clusters (A, B and C). Cluster A is made up of the seed mixture and relevés in areas where seed was sown more recently (2-3 years ago); cluster B corresponds to relevé 4 ; cluster $C$ groups the relevés carried out in sites where seeds were sown less recently (9-14 years ago).

The phytosociological table (Table 2) shows the floristic-physiognomic differences between the three clusters. Cluster A is composed mainly of herbaceous species of the classes Molinio-Arrhenatheretea and Artemisietea vulgaris, while cluster $\mathrm{C}$ has a number of shrubs of the class Rhamno catharticae-Prunetea spinosae, and species (grasses, shrubs and trees) typical of the mature woods of the class Querco roboris-Fagetea sylvaticae and, to a lesser extent, of the class Vaccinio myrtilli-Piceetea abietis. Cluster B has characteristics midway between the other two clusters: unlike cluster A, it has no Artemisietea vulgaris species and it is richer than cluster A in species of Rhamno catharticae-Prunetea spinosae and Querco roboris-Fagetea sylvaticae. The different physiognomy of the three groupings of vegetation is clear in the graph showing the indices of biological form (Figure 3). Cluster A has a high percentage of hemicryptophytes (which account for the entire mixture) and negligible amounts of IF (phanerophytes, nano-phanerophytes, chamaephytes and geophytes); cluster B presents a moderate percentage of IF, while cluster $\mathrm{C}$ has a higher percentage of IF, and the IH 


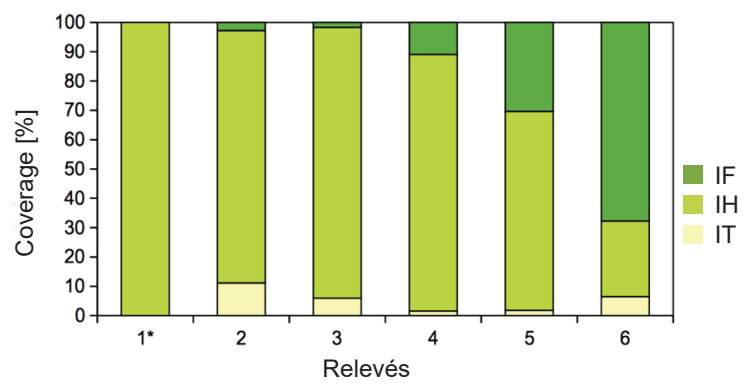

Figure 3 - Histogram of life form indices of relevés and seed mixture (1*). IT = index of therophytic component; $I H=$ index of hemicryptophytic component; IF = index of perennial non-hemicryptophytic component (geophytes, chamaephytes, nano-phanerophytes and phanerophytes).

value tends to be lower. Moreover, there is a moderate percentage of therophytes (IT index) in relevés 2 and 3 (cluster A), while in the relevés of clusters B and C the IT values are almost nil, except for relevé 6 . This is due to the fact that while the therophyte component of relevés 2 and 3 is made up of species belonging to ruderal, nitrophilous vegetation of the classes Stellarietea mediae and Artemisietea vulgaris, that of relevé 6 is represented only by Melampyrum pratense (with moderate coverage value), which is an annual species of mature broad-leaved forests (Querco roboris-Fagetea sylvaticae) and is not an indicator of disturbance.

The three groupings of vegetation also differ substantially in their chorological features (Table 2). Cluster A has a high percentage of species with widespread geographic distribution (cosmopolitan and subcosmopolitan) and an exotic species from North America (Erigeron canadensis), which is quite common in Italy in uncultivated areas. Clusters B and $\mathrm{C}$ differ from cluster $\mathrm{A}$ in the presence, albeit slight, of a contingent of endemic species of the Alps (Pignatti 1982): Phyteuma scheuchzeri, Phyteuma betonicifolium and Avenula praeusta.

From the ecological requirements of the coenoses synthesized by the average values of the indices of Landolt et al. (2010) shown in Table 2, it is clear that cluster A consists of heliophilous species that grow in soils which are rich in nutrients and moderately poor in humus, while cluster $C$ has more sciaphilous species, which prefer oligotrophic soils with medium-high humus content. The vegetation of cluster B presents ecological characteristics which are midway between clusters A and C. Taking into consideration the date of sowing in the various sampling areas, there was a gradual decline in ruderal species and an increase in competitive species over time (Table 2).

The graph in Figure 4 compares the time elapsed after sowing with the IM values of the five phytocoenoses, and shows the model which describes the trend of the IM over time. The graph shows a gradual increase in IM values from the site which was sown in 2012 (relevé 2) to the site sown in 2000 (relevé 6). In this case, the two variables (IM and time) are linked by

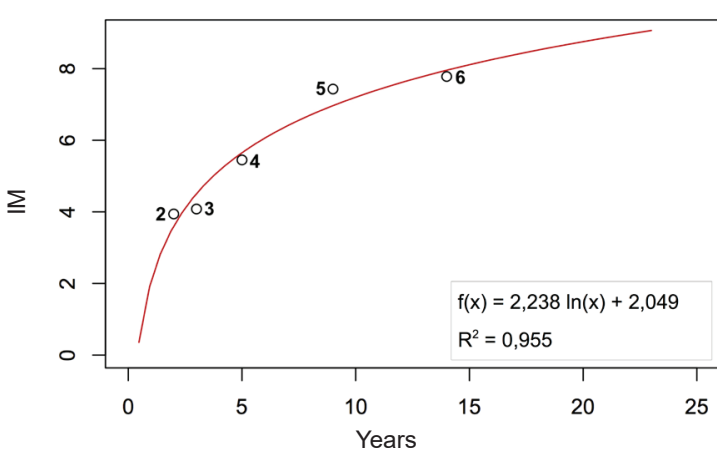

Figure 4 - Trend of the index of maturity (IM) over time (x) (years elapsed since sowing). Shown: relationship between the two variables, coefficient of determination $\left(\mathrm{R}^{2}\right)$ and function trend line. The numbers refer to the code of relevés.

a relationship $(\mathrm{IM}=2.238 \ln (\mathrm{x})+2.049)$ that accurately describes $\left(R^{2}=0.955\right)$ the trend of the IM over time (x). The model allows the identification of the time necessary for the system to reach the maximum IM value (mature vegetation), which in this case is about 22 years.

\section{Discussion and conclusion}

The results obtained from the analyses yielded a range of information on the characteristics of the vegetation of the five sites and highlighted the main changes (floristic, physiognomic and ecological) that occur over time in areas where seed mixture has been used. Cluster analysis divided the relevés into three groups: those in cluster A which represent the early dynamic stages of the series, and those in clusters B and $\mathrm{C}$ which describe more mature stages of the series. They are characterized by phytocenoses with different floristic composition, structure and ecological requirements. The decrease of heliophilous species over time after sowing is explained by the variation in the structure of the vegetation, with a clear predominance of herbaceous species in the early stages being gradually replaced by shrubs and trees, the shape of which allows most of the light energy to be captured, producing a selective pressure that leads to the appearance of sciaphilous nemoral species. Five years after sowing, species of the classes Artemisietea vulgaris and Stellarietea mediae, which are indicators of environmental disturbance, disappear, while some endemic elements appear. Over a number of years, the ruderal species decrease while the competitive species increase. This is in agreement with the model of Grime (2001) for the early stages of secondary succession in deforested areas on moderately fertile soils with a temperate climate, and as observed by Güsewell \& Klötzli (2012) in sown areas on roadsides in the Swiss National Park.

The mixture, whilst having the advantage of not containing exotic species, has the disadvantages of being poor in species and of including seeds from populations other than those in the area of study. The 
use of commercial seed in restoration can in fact alter the genetic diversity and structure of local populations (McKay et al. 2005; Aavik et al. 2012; Thomas et al. 2014); it would therefore be advisable to use autochthonous seeds better suited to the ecological conditions of the site, thereby avoiding (or reducing) genetic pollution. Improvements in the composition of the mixture (species and abundance), by using locally sourced seed, could implement ecological functionality and speed up succession (Prach et al. 2014). In general, the mixtures should reflect the communities that make up the early stages of the spontaneous dynamic series, knowledge of which is of paramount importance to enhance environmental restoration activities (Walker \& del Moral 2008). In this specific case, species of Calamagrostion arundinaceae (e.g. Calamagrostis arundinacea, Calamagrostis villosa, Lilium martagon and Molopospermum peloponnesiacum) and some elements of Sambuco racemosae-Salicion capreae (e. g. Salix caprea, Corylus avellana and Rubus idaeus) should be included. In fact, these species make up the communities of the initial stages of the dynamic series, i.e. of the fringe (Calamagrostion arundinaceae), followed by the mantle (Sambuco racemosae-Salicion capreae), and then the climax community (Piceion excelsae) (Verde et al. 2010). Promoting this dynamic series of vegetation would probably help the system to achieve the mature forest stage more quickly, reducing interference due to the presence of species that are not relevant to the stages of the series.

Where the analysis of the index of maturity (IM) is concerned, results showed that IM values increase over time after sowing. The identification of the relationship between IM and time elapsed since sowing has allowed the IM trend of dynamic series to be expressed mathematically. It has also provided an estimation of the time required for forest reconstitution which, in this case, was about twenty years.

Unfortunately, only a limited amount of data was collected in this study (only five relevés), and the seed mixture was used in only a few (and small) areas. We chose only areas which could actually be compared with each other (those with similar exposure, slope, altitude, substratum and environment), and where the mixture was sown in different years, in order to analyse the changes in vegetation over time. Nevertheless, the study yielded data and information which satisfied the requests of the managers of the two protected areas, who can now, with a more complete picture of the effects of the seed mixture, evaluate its use more carefully in future environmental restoration work. It would be interesting and desirable to apply the methods used in this study in other areas of the Alps where the same seed mixture was used, in order to improve understanding of the responses of vegetation in different environmental conditions. It would be equally interesting to compare the IM trends of the vegetation which develops after the sowing of different mixtures in order to identify those that, in the various environ- ments, allow the most rapid achievement of mature forest communities. Studies of this type might well provide important contributions to the fields of applied geobotany, forestry and restoration ecology.

\section{Acknowledgements}

We would like to thank Dr. Mario Tevini of the Consorzio Forestale Alta Valle Camonica for providing information about the mixture of seeds and sites where it was used. This study was supported by the Accordo di Programma affermazione in Edolo del Centro di Eccellenza Università della Montagna, MIUR - Università degli Studi di Milano, prot. n. 386 $1293-05 / 08 / 2011$.

\section{References}

Aavik, T., P.J. Edwards, R. Holderegger, R. Graf \& R. Billeter 2012. Genetic consequences of using seed mixtures in restoration: A case study of a wetland plant Lychnis flos-cuculi. Biological Conservation 145: 195-204.

Aronson, J. \& S. Alexander 2013. Ecosystem restoration is now the global priority: time to roll up our sleeves. Restoration Ecology 21(3): 293-296.

Biondi, E., C. Blasi, M. Allegrezza, I. Anzellotti, M.M. Azzella, E. Carli, S. Casavecchia, R. Copiz, E. Del Vico, L. Facioni, D. Galdenzi, R. Gasparri, C. Lasen, S. Pesaresi, L. Poldini, G. Sburlino, F. Taffetani, I. Vagge, S. Zitti \& L. Zivkovic 2014. Plant communities of Italy: the vegetation prodrome. Plant Biosystems 148: 728-814.

Bischetti, G.B., M. Di Fidio \& F. Florineth 2012. On the origin of Soil Bioengineering. Landscape Research 39: 583-595.

Blasi, C., G. Capotorti, R. Copiz, D. Guida, B. Mollo, D. Smiraglia \& L. Zavattero 2014. Classification and mapping of the ecoregions of Italy. Plant Biosystems 148(5-6): 1255-1345.

Braun-Blanquet, J. 1964. Pfanzensoziologie. Wien.

Grime, J.P. 2001. Plant strategies, vegetation processes and ecosystem properties. Chichester.

Güsewell, S. \& F. Klötzli 2012. Local plant species replace initially sown species on roadsides in the Swiss National Park. eco.mont 4(1): 23-33.

Hagen, D., T.-I. Hansen, B.J. Graae \& K. Rydgren 2014. To seed or not to seed in alpine restoration: introduce grass species outcompete rather than facilitate native species. Ecological Engineering 64: 255-261.

Kiehl, K., A. Kirmer, T.W. Donath, L. Rasran \& N. Hölzel 2010. Species introduction in restoration projects - Evaluation of different techniques for the estabilishment of semi-natural grassland in Central and Northwestern Europe. Basic and Applied Ecology 11: 285-299.

Landolt, E., B. Bäumler, A. Erhardt, O. Hegg, F. Klötzli, R.W. Lämmle, M. Nobis, K. Rudmann-Mayree, H.F. Schweingruber, J.P. Theurillat, E. Urmi, M. Vust 
\& T. Wohlgemuth 2010. Flora indicativa. Ökologische Zeigerwerte und biologische Kennzeichen zur Flora der Schweiz und der Alpen. Bern-Stuttgart-Wien. [In German]

McKay, J.K., C.E. Christian, S. Harrison \& K.J. Rice 2005. "How local is local?" - A review of practical and conceptual issues in the genetics of restoration. Restoration Ecology 13(3): 432-440.

Martini, F., E. Bona, G. Federici, F. Fenaroli, G. Perico, S. Danieli, G. Fantini, L. Mangili, F. Tagliaferri \& E. Zanotti 2012. Flora vascolare della Lombardia centroorientale. Trieste. [n Italian]

ÖAG - Österreichische Arbeitsgemeinschaft für Grünland und Futterbau 2000. Richtlinie für standortgerechte Begrünungen. Irdning. [In German]

Pignatti, S. 1982. Flora d'Italia. Bologna. [In Italian]

Pignatti, S. \& F. Mengarda 1962. Un nuovo procedimento per l'elaborazione delle tabelle fitosociologiche. Accademia Nazionale Lincei Rendiconti Classe Scienze Fisiche Matematiche e Naturali Serie VIII 32: 215-222. [In Italian]

Prach, K., I. Jongepierová, K. Rehounková \& K. Fajmon 2014. Restoration of grasslands on ex-arable land using regional and commercial seed mixtures and spontaneous succession: Successional trajectories and changes in species richness. Agruculture, Ecosystems and Environment 182: 131-136.

Previtali, F., D. D’Alessio, A. Galli \& L. Tosi 1992. I suoli, i paesaggi fisici, il dissesto idrogeologico in Val Camonica e in Val di Scalve (Alpi Meridionali). Monografie di "Natura Bresciana" n. 17. Museo Civico di Scienze Naturali, Brescia. [n Italian]

R Development Core Team 2015. R: A language and environment or statistical computing. R Foundation for Statistical Computing, Vienna, Austria. Available at: http:/ /www.r-project.org

Raunkiaer, C. 1934. The life form of plants and statistical plant geography. Oxford.

Rismondo, M., A. Lancioni \& F. Taffetani 2011. Integrated tools and methods for the analysis of agroecosystem's functionality through vegetational investigations. Fitosociologia 48(1): 41-52.

Taffetani, F. \& M. Rismondo 2009. Bioindicators system for the evalutation of the environment quality of agro-ecosystems. Fitosociologia 46(2): 3-22.
Thomas, E., R. Jalonen, J. Loo, D. Boshier, L. Gallo, S. Cavers, S. Bordács, P. Smith \& M. Bozzano 2014. Genetic considerations in ecosystem restoration using native tree species. Forest Ecology and Management 333: 66-75.

Walker, L.R. \& R. del Moral 2008. Lessons from primary succession for restoration of severely damaged habitats. Applied Vegetation Science 12: 56-67.

Verde, S., S. Assini \& C. Andreis 2010. Le serie di vegetazione della regione Lombardia. In: Blasi, C. (ed.), La vegetazione d'Italia: 181-203. Roma. [In Italian]

\section{Authors}

Luca Giupponi - Corresponding author

is a botanist of Ge.S.Di.Mont. and expert on flora of the Alps, plant ecology and phytosociology. He studies plants and plant communities and everything related to the valorization of mountain areas.

Centre of Applied Studies for the Sustainable Management and Protection of Mountain Areas, Ge.S.Di. Mont., University of Milan, Via Morino 8, Edolo, 25048 Brescia, Italy. E-mail: luca.giupponi@unimi.it

\section{Gian Battista Bischetti}

is Associated Professor of Agricultural Hydraulics and Watershed Protection at Università degli studi di Milano. He is particularly active in the fields of soil bioengineering techniques, slope stability in forested hillslopes and in the environmental design of rural watercourses.

\section{Annamaria Giorgi ${ }^{1}$}

is the director of Ge.S.Di.Mont. and experienced in dealing with research activities in the management of public institutions. She was president of ISCAR and now she represents the Lombardy Region in the EU Strategy for the Alpine Region.

${ }^{1}$ Department of Agricultural and Environmental Sciences-Production, Landscape, Agroenergy University of Milan, Via Celoria 2, 20133 Milan, Italy. 